\title{
Anjel Lertxundiren pertsonaien izenak \\ The names of the characters in Anjel Lertxundi's works
}

\author{
Karlos Cid Abasolo \\ Universidad Complutense de Madrid
}

Izena duenak izana ere badu

Euskal esaera zaharra

-iJoseba es Jose en vasco!

Eta nik neure artean:

- José euskaraz ez al da ba Joxe?

Anjel Lertxundi

\begin{abstract}
A Basque proverb literally says, "he wholthat which has a name also has a being". This is literally advocated by Anjel Lertxundi, if bearing in mind the criteria used by this Basque writer when it comes to naming characters. As is the case with the rest of literary choices, Lertxundi provides his characters with a specific name only after a deep reflection. As a sign of his generosity, Lertxundi gives a detailed account of this particular writing process in his essays, lectures and press columns. These are valuable sources for the data and conclusions that will be fully explained throughout the article.
\end{abstract}

Keywords: anthroponomy, literature, metaliterature, names created by Sabino Arana.

\section{Laburpena}

Euskal esaera zaharrak dioenez, izena duenak izana ere badu, eta hala uste du Anjel Lertxundik, erreparatzen baldin badiegu bere eleberrietako pertsonaien izenak hautatzerakoan erabiltzen dituen irizpideei. Gainerako literatura hautuetan bezala, Lertxundik gogoeta sakon baten ondorioz ematen die bere pertsonaiei honako edo horrako izena. Eta, txit eskuzabala denez, idazte prozesu horren berri zehatza ematen digu bere saiakera, hitzaldi eta prentsa-zutabeetan, bai eta, gure kasuan bezala, harekin aurrez aurre gaudenean ere. ${ }^{1}$ Iturri horietatik guztietatik ateratakoak dira hemen aletzen ditugun datu eta ondorioak.

Gako hitzak: antroponimia, literatura, metaliteratura, izen aranatarrak.

${ }^{1}$ Gure eskerrik beroenak eman nahi dizkiogu Anjel Lertxundiri artikulu hau paratzeko eman dizkigun informazio ugariengatik. Oso eskuzabal erantzun zion gure galdera sortari. Zarauzko Alameda kafetegian izan genuen hitzordua, eta gainerako bezeroak inauteriak zalapartaka ospatzen ari ziren bitartean, guk literaturaz eta antroponimiaz ihardun genuen, inauteriei exotismo ukitu bat eman nahiz-edo. 
Anjel Lertxundiren zenbait obratan, memoria da gai nagusietako bat. Eta beste gai edo helburu bat, euskal literatura ahozko eta idatzizkoaren tradizioa berreskuratzea eta «birsortzea». Birsortzea, aurreko hainbat literatura materialen erabilera abiapuntutzat hartuta, sortzera iristen da, istorio orijinaletara. Zentzu honetan, euskal kultura zorretan dago Lertxundirekin, bestela ezagutuko ez liratekeen material horiek guztiak euskaldunon eskura jartzeagatik. Haren Piztiaren izena eta Konpainia noblean liburuek, kasu, leitv-motiv hori dute funtsean.

Bada, euskal kulturaren memoria berreskuratzeko ahalegin handi horretan berebiziko garrantzia du antroponimiak, bestela esanda, Lertxundik sortutako edo birsortutako istorioetako pertsonaien izenek. Ez alferrik, aipaturiko bi obra horien kapituluek pertsona-izenak dituzte izenburu.

Pertsonak eta gauzak izendatzeko gizakiok dugun joerak balio erantsia du euskal kulturan. Hala frogatzen du hasierako esaera zahar ezin ezagunago eta euskara idatzi zein ahozkoan maiz erabiliak.

Artikulu honetan Lertxundiren hiru motatako lanak aztertuko ditugu: eleberriak, zeinetan idazle honen praxi antroponimikoa jorratuko dugun, eta antroponimia aztergai duten saiakerak eta prentsa-zutabeak. Hortaz, ikerketa eremua murrizte aldera, narrazioak $^{2}$ baztertuko dira ikerketa honetatik, bai eta haur literatura ere, aipu konkreturen bat egiteko ez bada.

Lertxundik antroponimiari ematen dion garrantzia bere Hitz beste blogean egiazta daiteke, zeina Berria egunkarian argitaratzen baitzuen. Hitz bestek bazuen sail bat Letrak sare-kantoitik izenekoa, eta Lertxundik hor 2009ko otsailean plazaratutako testuren batzuk antroponimiaren ingurukoak dira: «zenei irri», «Balantxasen omenez», «Izena izanaren izara» eta «Marimin du grazia».

Idazle oriotarrak istorio bat garai eta toki jakin batean kokatzen duenean, garai horri eta toki horri dagozkien izenak aukeratzen ditu, jakina, bere pertsonaientzat. Hona hemen adibide bat: Hamaseigarrenean, aidanez eleberria (1983koa, Lertxundiren estreinakoa) euskal baserri girokoa da eta Orio, Aia eta Urdaneta udalerriak ditu kokagune. Eta, koherentzia hutsez, bere gurasoen garaiko izenak aukeratu zituen pertsonaientzat, hain zuzen ere, orduko «Euskal Herri sakonean» nagusi zirenak: izen luzeak, hiru edo lau silabakoak: Josefina, Kornelio, Martzelina edo Domingo, ${ }^{3}$ zeren erdal izenak (edo, nahiago bada, "nazioartekoak», euskarara latin edo espainieraren bidez iritsitakoak) baino ezin baitzitzaizkien jarri garai hartako euskaldunei, nahiz eta eguneroko bizitzan izen horiek euskal «mozorro» fonetikoaz jantzi (Iñaxi, Koxme...). Ohargarria da eleberri horretako pertsonaia batek —Josefinaren semeak- Joseba duela izena, eta ez da kasualitatea: pertsona-izen aranatarrak, frankismoan debeka-

\footnotetext{
2 Piztiaren izena ipuin bilduma izan ezik, zeren Azkenaz beste eta Argizariaren egunak eleberriekin batera trilogia bat osatzen baitu eta bukaeran glosategi luze bat baitakar, liburua narrazio eta saiakeraren arteko hibrido bihurtuz.

3 Bere blogean («Marimin du grazia», Letrak sare-kantoitik, 10, Berria, 2009-2-15), honela diosku Lertxundik: «Sar nadin, Lizardiren bide bertsutik, etxe-barne bizitzan eta begira ditzadan nire gurasoen belaunaldiko senideen izenak: Domingo, Josefina, Hipolita, Dionisio, Agustina, Inazio Mari, Nikolas, Klemente, orain hamar egun hil berri den izeba Justina...». Bestalde, eleberri honetan, mendetako euskal baserri giroan ohi zenez, zenbait pertsonaiaren izena jatorriaz lagunduta agertzen dira: Aldapeko Julian, Artadiko Koxme, etab.
} 
tuak, biziki zabaldu ziren xx. mendeko 70eko hamarkadatik aurrera. Garai hartan gertatu zen euskal belaunaldien arteko haustura antroponimikoa. ${ }^{4}$

Hamaseigarrenean aidanez-eko istorioa zenbait pertsonaiak kontatzen dute zatika puzzle bat osatuz bezala, eta eleberriaren erdira arte ez gara jabetzen zati horiek istorioaren ardatz den eta eleberriari izena ematen dion tragediaren lekukoek kazetari arrotz bati egiten dizkioten adierazpenak direla. Gogora dezagun pertsonaia arrotza Lertxundik geroko beste eleberri batzuetan (hala nola Otto Petten) darabilen baliabide bat dela eta ohikoa duela pertsonaia baten edo batzuen izena isiltzea, bai eta haien nortasunarekin jolastea ere. Hamaseigarrenean aidanez-i dagokionez, inoiz ez zaigu esaten nola duen izena kazetari horrek. Anonimotasuna irakurlearengan misterioa eta asaldura eragiten dituen prozedura bat da. Badirudi irakurleok azkenik dakigunean nola duen izena honako edo horrako pertsonaiak, lasaixeago gaudela, erlaxatu egiten garela, hobeto «ulertzen» dugula istorioa. Eta Lertxundik, ordea, nahiago du beti ere erne egon gaitezela, atezuan bezala.

1987ko Tobacco days eleberriko pertsonaien izenak Hamaseigarrean aidanez-ekoen tankerakoak dira: Tomax, Hilario, Manuel, Exteban, Ramon, Natxo, Julio, Pilar, denak erdal jatorrikoak, eta hiru multzotan sailka daitezkeenak:

- Euskal «mozorro fonetikoa» dutenak, kontsonante txistukariaren ohiko bustidura eta guzti: Tomax, Exteban.

— Espainieraz bezala ahoskatu arren, euskal ortografia dutenak: Natxo, Ramon (azenturik gabe).

— Espainieraz bezala ahoskatzen eta idazten direnak: Hilario, Manuel, Julio, Pilar.

Antroponimiak rol garrantzitsua jokatzen du hurrengo eleberrian: Carla (1989) izenekoa da eta Parisen girotutakoa. Protagonista komiki-marrazkilari bat da, Lertxundik Gortari izena ematen diona, nahiz eta, Edorta Jimenezek dioenez (1989), ez dagoen argi hori bere benetako izena ote den. Edozein modutan, idazle oriotarrak Edorta Kortadi irakasle eta arte-kritikariarengandik «mailegatu» zuen deitura hori. Lertxundik komikietara zaletu zen garai batean idatzi zuen liburu hau. Izan ere, Carlan ageri den Duca Ursini pertsonaia Ugo Prat marrazkilariari egindako omenaldia da, Pratek sortu baitzuen Duca izeneko pertsonaia bat. Gainera, garai bereko komiki askok nortasunaren arazoa izan zuten gaietako bat. Pertsonaien izenen hautuan biziki eragin zioten Lertxundiri bere orduko irakurgaiek (Albert Camus, Jean-Paul Sartre, Georges Bernanos, eta abarrek). Carlaren protagonista bere deituraz aipatua da beti, harik eta 81 . orrialdean, azkenik, haren izenaz jabetzen garen arte promesa bati

${ }^{4}$ Honela dio Lertxundik (ibidem): «(...), hamabi bat urte izango nituen nik, mutil bat ezagutu Saturraranen, eta izena galdetu zidan. Nirea eman eta gero, bereaz galdetu nion. «Joseba», erantzun zidan. Nire umetan jatorri sabindarreko izen gutxi zen Orion - "Orio no es precisamente un foco del nacionalismo vasco", dio Ana Maria Etxaidek 1968an argitaratu zuen Castellano y vasco en el habla de Orio liburuan-, eta Joseba zer izen klase ote zen galdetu nion nik mutil ezagutu berriari. Garai haiek bortxatu gintuzten maneran ari ginen biok, gaztelaniaz alegia, eta lagun egin berriak, urteak aurrera areagotu egin zaion itxura serio autoritarioaz:

—iJoseba es Jose en vasco!

Eta nik neure artean:

-Jose euskaraz ez al da ba Joxe? 
esker: «Ez du inork Rafael Gortariren ahotik zure berririk izango, Carla». Bestalde, liburuari izena ematen dion pertsonaiarekin maitemintzen da Gortari, eta izen hori ez zaio irakurleari jakinarazten 56. eta 57. orrialdeetara arte. Izen eufoniko bat, ozena, Gortarik bere komikirako asmatutako patio veneziarrarekin zordun dagoena.

Lertxundik aitortu digunez, eleberri hau izkiriatzen hasi zenean ez zeukan artean aukeratuta izenburua, eta egun batean, zati handi bat idatzita zeukanerako, bizilagun bat bere alabari «Carla, etorri hona!» esaten entzun zuen. Hortaz, hemen (beste askotan bezala) egiaztatzen dugu idazte prozesua literatura material ere badela Lertxundirentzat. Berak eta Gortarik aldi berean deskubritzen dute komikiaren pertsonaiaren izena, eta Gortariri gertatutakoa Lertxundiri ere gertatu zaio. Estrategia hori ohikoa du idazle gipuzkoarrak. Esaterako, Berriako Hitz besteren bertsio digitalean post scriptum bat zeukan, non bere testu labur bakoitzaren nondik norakoak argitzen zituen: zergatik eta nola idatzi duen hau eta beste, zergatik aukeratu dituen honako edo horrako hitzak, etab. Hitz batean esanda, metaliteratura egiteko beharra dauka, bere literatura zeregina irakurleari agerian uztekoa, bere trukuak azaltzen dituen magoaren antzera. Eta badakigu idazle eta mago guztiek ez dutela hala jokatzen: gehienek nahiago dute beren sekretuak ezkutatu.

Carla izena Lertxundirentzat aitzakia da beronen zaletasunetako baterako: hizkuntzarekin jolasteko, hain zuzen. Halatan, pasarte batean (129-130) amets gaizto moduko bat gogoratzen duenean, Carlania, Carlapolis, Bagni di Carla, Carlanova, Port Carla, Carlatower, Carlaura, Carla Lake, Carlammare, Carlaida, Carlareggio eta Carlamaggiore dakartza hizpidera. Hor nabarmena da Italo Calvinok 1969an argitaratutako Il castelo dei destini incrociati obraren oihartzuna. Idazle italiarraren eleberri horren bukaeran badago gauza bat Lertxundiz esan berri dugun zerbait gogorarazten diguna: Calvinok, horretaz interesaturik egon litezkeen irakurleengan pentsatuz, ohar bat eransten du, zeinean jakinaren gainean jartzen baititu erabilitako literatura teknikez.

1990ekoa da Lertxundiren hurrengo eleberria: Lurrak berdinduko nau. Protagonista aitona bat da, Jose (eta ez Joxe, hala idatzita ageri bada ere liburuaren atzeko azalean) izenekoa. Jose Zendoiaren haurtzaroko oroitzapenen bidez jabetzen gara Joseri, eskolan, Jariyo ezizena jarri ziotela bere gernu-inkontinentzia zela eta. Bestalde, Joseren izena eta deitura euskal grafiarekin idatzita ez dauden liburuko pasarte bakarra epai bat da, espainieraz idatzia, jakina, zeinean jakinarazten den heriotza zigorrera kondenatua izan zela gerra zibilean. ${ }^{5}$ Bilobarentzat, aldiz, Antton izena aukeratu zuen Lertxundik, baina eleberria argitaratu aurretik adiskide bati irakurtzen utzi eta lagunak izen hori aldatzea aholkatu zion aitona hitzaren oso antzekoa baitzen. Lertxundik ameto eman, German izena hautatu, eta ordenagailuko «denak ordezkatu» teklari sakatu zion. Liburua plazaratu ostean, editoreak estu eta larri hots egin zion, zeren Antton Valverde kantaria, narrazioaren bukaeran aipatua zena, modu misteriotsuan (eta betiko) German Valverde bilakatu baitzen. Sei urte geroago, Letrak kalekantoitik liburuan (171-172), umorez oroituko zuen pasadizo hura idazle oriotarrak.

\footnotetext{
5 «El Presidente del Tribunal de Seguridad Interior y Orden Público, una vez probada la participación de José Cendoya Juaristi en las hordas separatistas, en cumplimiento de la Ley Marcial, condena al susodicho José Cendoya Juaristi a la pena capital...» (18).
} 
1991 , Lertxundik Kapitain Frakasa argitaratu zuen, zeinean kontatzen diren talde klandestino batek Italia eta Frantziaren arteko mugan izandako gorabeherak. Ezkutuko giro hartan, eta idazleak berariaz hala erabakita, irakurlea nahikoa galdurik dabil, baita pertsonaiak ere, zeinek solaskidearen nortasuna jakin behar beti ez asea sentitzen baitute.

(...) ilunabarraren argi nagia jabetu zen gelaz eta, kandela koskor baten argira gorputz biluzia eskortzoan buhamearengana jiratuz, Moniquek galdetu zion:

Nor zara. Ez didazu oraindik esan zure izena.

Bidaiariak, masaila neskaren gerri biluzian, erregutu zion ez ziezaiola halakorik galde. Ez zezala zoritxarra tenta.

Ezetz, ez ziola izenik esango.

Zer ote zuen izena ezagutu ezinak txarrik. Ez duela izen propiorik arrastiritik gau bezperara bitarteko argi eroriak.

Moniquek, ordea: Ez al duzu ulertzen? Ai, ez baneki itsasoan euria egitea bezalako izatera ere irits daitekeela maitasuna, hel daitekeela egunez argi ustetan ari den ilargi izatera ere...

Bidaiariak, bide luzeko ihintzaren etsipen urratua begietan, aitortu zion:

Herio nauzu (28).

Protagonista, bere aldetik, kamuflaturik ageri da pasaporte faltsu baten eta nortasun askoren (hots, izen askoren: Ismael Osorio, Marcel, Antonio Cerdán) atzean, eta irakurleak bezalaxe, ez daki zeintzuk diren pertsonaia fidagarriak eta zeintzuk fidagaitzak.

Lauki gorridun kanadiar zamarra, pasaporteko bera, neraman soinean. Bi argazkien artean, ordea, ia bost urtetako tartea, Monique erakusten ari zitzaidan hartan Marcel, pasaportekoan Ismael...

Gustora zuzenduko nuke orain, argazkia eskutan izango banu, Moniquek atzekaldean idatzi zuen hura. Data zuzenduko nuke, izena ezabatuko, eta ez nintzateke berri bat jartzen hasiko ordainetan. Garai hartatik izen aldaketari buruzko galdera batek sortarazten dizkit burutazio nahasienak, gaur pentsatzera emana ea beharrezkoa ote genuen Marcel edo Cerdán haien moduko hainbeste asmazio, izen ugarien galerian ia ahazteraino geure benetakoak.

Galeriako izen guztiez aritu beharko banu, bestetik, Marcelen garaiari aitortu beharra diot oso maitale kaskarra izan nintzaiola Moniqueri. Higuina ere hartu nion garai hartan gonen atzetik ibili beharrari. Gehiegi janaren ondorengo lo kuluxketan bezalatsu, Moniquerekiko Marcel nintzen hartan. (...).

Orduan ez nuen hartaz jabetzeko batere arretarik erakutsi, eta nire ezjakintasun kutiziatu hartan erabaki nuen, izenez aldatzera behartzen nintzen bakoitzean, ahalegindu behar nuela abentura berri baten aukera gozatzera, Gerald D.k betidanik ohi bezala.

Moniquek ez zidan inoiz barkatu Marcelen ondoren Cerdán bilakatzeaz gain, aldartea ere aldatu izana:

-Marcel...

-Cerdán... Antonio Cerdán...

Bakarrik gaude. Marcel, Martin, Paul, Antonio... Zer axola ote du izen baten gorabeherak?

- Aurkitu dut Cerdán deituko didanik...

Bapatekoa izan zen efektua. Cerdán deitzen omen zidanaz interesatu zen modu zakarrean (...). 
Konturatu zen hizketagai genuenaren asmazioaz, ordutik aurrera sarri deitu zidaneta Cerdán, ironiaz baino areago barre lasai askoa eginaz eta azentu espainolarekin indartuz azken silabaren kanpai hotsa.

Farfailak farfaila, ez nuen sekula lortu suntsitzerik nire izen ugarien eta munduaren artean zegoen barrera.

Ez, ordea, ahalegindu ez nintzelako: Ezagutzen nindutenek izen aldaketa bakoitzarekin desberdin ikus nintzaten ahalegindu nintzen, fortuna desberdinarekin, deskalabruak pitzatu zituenean ordurarte Moniquerekin bizi izandako bost urte gorabeherez bete haiek.

Eta izen aldaketarekin batera, norekin nengoen, eta aldarte desberdinez jokatzeak erakutsi zidan benetako nortasuna saihestu eta identitate berrien erabilkerak, zuhurtziak derrigortua denean, baduela maskara dantzarekin antzik.

-Ismael Osorio?

-Oui... (71-73).

Aipatutako hiru izenetatik, Antonio Cerdán nabarmendu beharra dago. Gehienetan, deitura soilaz aipatua da, Lertxundik hizkuntzarekin jolasteko duen zaletasunaren erakusgarri: izan ere, espainierazko deitura horrek badu euskal esaldi baten itxura (zer dan).

Eleberriko beste hainbat izen Estatu Batuetako zinemagintzakoak dira: Orson (Wells), Josep Cotten, etab. Gogora bedi kultura erreferentzia anitzen erabilera (kasu honetan, erreferentzia antroponimikoena) dela Lertxundiren literaturaren ezaugarrietako bat, eta, hortaz, gustukoenak dituen irakurgai eta filmak omentzen dituela bere liburu ugaritan.

Batzuetan, antroponimiak Kapitain Frakasako pertsonaien denbora-pasa funtzioa ere badu. Izan ere, ezezagun bati izen jakin bat esleitzen diote arrazoi askotarikoengatik.

Mauricek bi behatzekin klaska! eta neska gazte bat agertuko zen foyer-era. Ardine, Aiguebelle, Magloire, Linie, Gentiane... Nola moldatzen zara izen guzti horiek asmatzerakoan?, galdetu nion behin Mauriceri. Suarekin zerikusia zutela erantzun zidan. Suarekin? Bai, suarekin. Neska sutsuenari graduazio handiko likore baten izena ematen diot. Neska bat sartu zen une hartantxe foyer-era. Atsegin al zaizkizu gereziak? Baietz, nik. Cerasella du izena, Mauricek, eta bultzada txikia eman zion hamalau urte izango ez zituen gorriz jantzitako neska koskorrari nireganantz (67-68).

Festa antroponimikoak ez du amaierarik eleberri honetan, nortasun bakar batek izen bat baino gehiago ezkutatzen baititu.

—Merçi... Adieu! —eta tom, tom-trak, tom, entzun zen trena orduantxe Jerry bataiatzea erabaki nuenak gure bagoi erdi hutsetik bagoi berrira pasatzerakoan atea irekitzearekin batera. (...).

Ziur nengoen ez zuela ezer sinetsi. Adieu, Tom; adieu, Ismael; adieu, Marcel. Zer axola ote zitzaion? Abisu ematen ariko zen ordurako Ventimiglia-ko aduanako jendarmeei (75-76).

Zaila gertatu zitzaidan sinestea irribarre lasai haren jabea eta lehentxeago Jerry bataiatu nuen polizia pertsona bera zitezkeenik (80).

(...) Etienne Piccard, gero Patrick deituko geniona (...) (103). 
1994koa da hurrengo eleberria: Otto Pette, Erdi Aroan kokatua. Ezezagun baten etorrera du abiapuntu (ezezagun bat berriz ere). Otto Pette baronetaren gotorlekura iritsi eta harekin denbora luzean solastatzen da. Azter ditzagun liburuko zenbait pertsonaiaren izenak, gehienak zubererazko palatalizazioez blaituak:

- Otto Pette: protagonista da, erregearen kontseilaria. Berak ematen digu bere izenaren edo, hobeto esanda, ezinezaren berri.

Hura guztia berritu zidan, ordea, arrotzak botatako izen bikoitzak: Otto Pette. Bi leherraldi behar dituen trumoiaren antzera entzun nituen Pette nire benetako izenaz jokatuz gaitzizena osatzen zuten hitzok. Niri zegozkidanak izanda ere, aspaldi handian inori entzun ez, eta guztiz harrigarri gertatu zitzaizkidan arrotzari entzun nizkionean. Otto deitzen ninduten estraina, Grazibelen osaba ere banintzenez, jendeak irriz ttettekatzen baitzuen nire deitura. Grazibel eta nire artekoak zoko, azoka eta tabernazulo guztietako itsu-paperetako gai eta esames bihurtu ahala; baina Otto, batez ere, Julius Probori legnum veritatis hura eginarazi nionetik: otsoak ardiak sarraskitzen dituenean bezala gozatzen omen duk, laburtu zidan behin Erregek jendearen ahotan zebilen ustea... (51-52).

— Grazibel: Otto Petteren iloba eta maitalea. Bi izen batera dakarzkigu gogora: Graziana eta Isabel.

- Aba Yakue: fraidea eta Otto Petteren lehiakidea. Aba tratamendu eklesiastiko bat da, «aita» esan nahi duena. Yakue, berriz, Santiagoren izen euskalduna (Done Jakue bidea...).

- Arrotza: Otto Pettek ez daki nor den, eta arrotzak ere ez dio erraztasunik emango, baina, hori bai, lagunduko dio haren bizitzaren errespasoa egiten. Horretarako, arrotzak zenbait nortasun hartuko ditu, zenbait izen, aurreko liburu batzuetako teknika errepikatzen delarik. Hala, atal batean Errondal pintorea izango da; beste batean Battis Tobera, bere txakurra lagun, itsu koplak kantatzen dituena; geroago, Manex Muxela ${ }^{6}$.

- Julius Probo: hemen autoreak nahiago izan du izena era latinean gorde, eta adjektiboa/deitura, ordea, «ondratua» eta "prestua» esanahia duena, forma erromantzearekin, Probus formaren kaltean.

- Battis Tobera: Battis destainazko izengoitia da, mendebaleko euskalkietako Bautista $^{7}$ izenaren baliokidea. Eta Tobera, jakina den bezala, bere adieretako batean, frantsesezko charivari hitzarena: herri antzerki mota bat, maskarada mota bat, ezkongaiak isekagai zituena «ez ohiko arrazoiengatik»e ezkontzen zirenean. Hortaz, gaitzizen ezin egokiagoa da kasu honetan: gaztetan, Battis emaztegaiak engainatua izan zen, eta hori gutxi balitz bezala, mutilaren aitarekin.

— Beste izen batzuk: Katixa (Erdi Aroko hipokoristikoa, Katalinen baliokidea); Añes (Agnesen aldaera, bustidura eta guzti).

Bestalde, Lertxundik, maiz-maiz, zuberera zaharreko ohiko tratamendu bat, frantsesetik datorrena, erabiltzen du eleberri honetako hainbat pertsonaia izendatzeko.

\footnotetext{
${ }^{6}$ Gogora dezagun Manex Joannes izenaren hipokoristikoa dela eta zuberotarrek gaitzizen hori erabiltzen dutela baxenabartarrei batik bat eta, oro har, euskaldun guztiei destainaz esateko.

7 Esaterako, hala du izena Bautista Basterretxe kantaren protagonistak.
} 
Monsieur de-tik eratorritako $M u s d e^{8}$ da gizonezko aldaera, eta hala ditugu, besteak beste, Musde Dexes, Musde Bixinto, Musde Bertholet, Musde Arnoldo, Musde Matheus, Musde Beñat, Musde Kanpix, Musde Manex. Mademoiselle de-tik eratorritako Mamiñun ere badarabil Lertxundik zenbait emakumezko pertsonaia izendatzeko, hala nola Mamiñun Agatha, Mamiñun Maialen eta Mamiñun Kattalin.

1995ean, Lertxundik Ifrentzuak izeneko liburu bilduma idazteari ekin zion. Besteren literaturetan bizitza errealean baino gehiago oinarrituz, unibertsala eta partikularra aldarrikatzen ditu Lertxundik Ifrentzuak bildumako liburuotan. Unibertsala eta partikularra euskal kulturaren eta beste edozein kulturaren ezinbesteko osagarriak dira, Lertxundiren aburuz. Iritzi bertsua agertu du, bidenabar esanda, bere zenbait saiakera eta hitzalditan. Honatx bildumako liburuak:

- Piztiaren izena (1995): bi zati ditu. Lehenengoa, deabrua eta Faustoren mitoa ardatz dituzten bost ipuinez osaturik dago. Bigarrena glosategi bat da, bost istorio horiek eta Euskal Herriko eta, oro har, Europako tradizioen beste misterio batzuk ulertzen laguntzen diguten hitzena.

- Azkenaz beste (1996): hirurehun urte dirauen bidaia fantastiko baten kontakizuna. Bi bidaiari protagonistek Estatu Batuak, Katalunia eta Euskal Herria zeharkatzen dituzte.

- Letrak kalekantoitik (1996): esaera zahar, mito eta herri kanta ugariren glosategia.

- Argizariaren egunak (1998): hausnarketa sakonak tartekaturik dituen metaerrelatoa.

Piztiaren izena liburua izenburutik bertatik zaio interesgarri gure ikerketari. Egileak aurreratzen digu liburuan deabruaz jardungo duela, bai eta deabruari zenbait kulturatan (euskalduna barne) ematen zaizkion izenez ere. Bestalde, lehenengo bost ipuinen izenburuak izen bereziak dira: Bettini Txerren, Akilimarro, Gilles de Rais eta Lilith. Txerren eta Akilimarro deabruari deitzeko euskal hitzetako bi dira. Lertxundik kapitulu oso bateko gaitzat hartuko zuen Txerren geroko liburu batean (Konpainia noblean, 34-36).

«Lilith» ipuinean bada euskal ahozko tradizioko pertsonaia bat: Maria Kirikitun sorgina. Borreroak, erre baino lehenagoxe, honela diotso, errimak esanahiari ematen dion indarrarekin eta heriotza zigorrari ahazturaren (izenaren ahazturaren) kondena erantsiz: «Kiskal hadi, Maria Kirikitun: hire izenaz nehor oroituko ez dun!».

Ez da harritzekoa glosei buruzko kapituluko glosa bat «Izenak» deitzea, zeren ugari baitira euskaraz deabruari esateko ditugun berbak. «Nola deituko diogu, bada, izen bakar batez, etengabe metamorfoseatzen den izaki bati?» (171), itauntzen du erretorikoki Lertxundik. Bestalde, atentzioa ematen du izenen artean bi izen berezi izateak: aipatutako Txerren eta Infernuko Patxi.

Maria Kirikitunen glosan, Lertxundik jakinarazten digu pertsonaia hori Bere arima saldu zuen neskatoa izeneko kontu zahar Jean François Cerquandek bilduan ageri dela. Neska batek noble batekin ezkontzeko zazpi alkandora josi behar dituenez, Maria Kirikitunek laguntzen dio. Sorginak jartzen dion baldintza Lertxundiren

8 Musde esapidearen bukaerako de hori euskarazko jatorria adierazten duen - $k$ o atzizkiaren baliokidea da, eta Hamaseigarrenean, aidanez aztertzean esan genuen bezala, euskal baserri giroko gizartean atzizki hori izenari erantsi ohi zitzaion jaioterri edo jaiotetxea adierazteko. Musde (eta Murde aldaera) gerora glosatuko zuen Lertxundik Letrak kalekantoitik liburuan (282). 
bi gai gustukoenetarikorekin dago loturik: oroimenarekin (orhoitu aditzaren bidez) eta antroponimiarekin (izena substantiboaren bidez). Eta bi gaiak lotzen dituen «Lilith» ipuinaren erremate errimadun bera ageri da hemen ere.

- Nahi badautan hitz eman —erraiten du emazte xaharrak, zoin bait zen sorgin bat - hemendik urthe baten burian orhoituko hizela ene izenaz, eta orhoitzen ez bahiz, hihaur enetako izanen hizela nik nahi dutana hitaz egiteko, egiteko daunat hire lana memento batez.

-Eta zer da zure izena?

- Maria Kirikitun,

nire izenaz nehor orhoituko ez dun (178).

Azkenaz beste eleberrian, kalesa batean eternitatetik noraezean ibiltzera kondenaturik daude Nora eta bere aita. Sei ataletako bostek leku-izena dute: Bartzelona, Salem, Boston, Baiona eta Zarautz, istorioaren (istorioen) garai oso ezberdinetako eszenatokiak. Hortaz, oraingoan, atalak izendatzeko, Lertxundik leku-izenak nahiago izan ditu pertsona-izenak baino. Espainierazko itzulpenaren izenburuan (Un final para Nora), ordea, pertsona-izen bat ageri da, protagonista emakumezkoarena. Eta izen horretan bada Lertxundiren beste jolas linguistiko bat, zeren eta, jakina denez, Nora, izenaz gain, galdetzailea ere bada euskaraz, hemen noraezeko bidaiaren ideia azpimarratzen duena. Irati Jimenezek hitz joko bera erabiliko zuen 2009ko Nora ez dakizun hori eleberrian.

Azkenaz beste liburuak, aurreko eta geroko beste batzuek bezala, kultura unibertsala (oro har) eta euskal kultura (partikularzki) omentzen ditu. Zenbait pertsonaiaren izenak ez dira kasualitatezkoak. Mundu errealetik eta literaturazkotik hartuak dira: Martha Cory (Salemeko sorginetako bat), Nathaniel Hawthorne, bere pertsonaia Hester Prynne, Jean Duvoisin, edo Van Eys hizkuntzalari herberehetarra, zeina eleberrian beti aipatua baita bere ponteko izenez (Willem).

Letrak kalekantoitik euskal kantutegitik eta ahozko eta idatzizko literaturatik jasotako hainbat esaera zaharren glosategia da. Lertxundik ematen dizkigun azalpenetan narrazio laburrak, etimologiak, pasadizoak eta herri kantei buruzko hausnarketak tartekatzen dira. Beraz, idazle gipuzkoarrak hitza omentzen segitzen du hemen ere, hots, euskal aberastasun linguistiko eta kulturala biltzen. Bukaerako Ohar Bibliografikoan aitortzen du lau eredu izan zituela inspirazio-iturri: Joseba Sarrionandiaren $N i$ ez naiz hemengoa, José María Iribarrenen El porqué de los dichos, Claude Dunetonen La puce à l'oreille eta Néstor Lujánen Cuento de cuentos. Lertxundiren glosategi honetan bada euskal antroponimiari buruzko iruzkin interesgarri bat Jel akronimo sabindarraren inguruan:

Nikolas Altzolak Jel (Jaungoikoa eta Lege zaharra) izeneko bi gizasemeren berri eman zuen aldizkari batean, Aberri, Zigor, Mendeku, Harri, Iraultza eta antzeko izenak ere gizonezkoei bakarrik jartzen zaizkie, euskal izenek jenerorik ez dutela irakatsi zaigun arren (227).

1998koa da Argizariaren egunak eleberria. Hor heriotza, obsesioak eta idazketa ditu Lertxundik gai eta hizpide. Bi plano daude Ipar Euskal Herrian eta Bordelen girotutako istorio honetan:

Alde batetik, Mikel izenaren hipokoristikoa den Mitxel izeneko protagonista-narratzaileak ekoiztetxe batean telebistarako free-lance gisa lan egiten du. Bere bi lanki- 
deek Bibliako izen hebrear bana dute: Ada («apaingarri» esan nahi duen «adah» izenetik eratorria) ${ }^{9}$ eta Danel (Aranak eta Elizaldek asmatutako aldaera), "Jainkoa da nire epailea» esan nahi duena. Mitxelek Ada lankidearekin bizi duen amodiozko istorioa kontatzen du, tragikoki amaitzen dena.

Beste aldetik, zenbait urte geroago Mitxel erietxe psikiatriko batean sarturik egongo da (ero ote dagoen edo delituren bategatik preso ote dagoen inoiz jakingo ez delarik) eta ezbaian jartzen du lehenago kontaturiko amodiozko istorio hori.

Izen aranatarra duen beste pertsonaia bat Koldo ${ }^{10}$ da, Azkona Estudioko programa-burua. Ez da kasualitatea une jakin batean (188) Lertxundik pertsonaia honen bidez euskal deituren inguruko txantxak egitea, Koldok Mitxeli esaten dionean:

Basileako Ituna eta Domingo de Iriarte diplomatikoa ('Puerto de la Cruz-en jaio zuan Iriarte, itunaren aita, baina ea euskal arrastorik ateratzen dioan. Deitura horrekin... (184).

Liburu honetako antroponimo guztiak bi silabakoak dira. Lertxundik dioskunez, Euskal Telebistaren sorrerako giroan oso ohikoak ziren izen horiek edo antzekoak.

Egileak, aurreko zenbait obratan bezala, hemen ere Europako literaturarekin lotutako izenak aipatzen ditu (Bürger), bai eta euskal literaturakoak (Pouvreau, Beñat Etxepare, Orixe) eta zenbait pertsonaia historiko ere (Tomas Zumalacarregui). Eta beste askotan egin duen bezala, lehenengo pertsonaren atzean ezkutatzen denaren nortasuna istorioa nahikoa aurreratuta dagoenean jakinarazten digu, oraingo honetan ohar soil baten bidez.

Arestian ere esan dudanez, itxaropenaren kriskitinak entzuten egon nintzen astearte arratsaldean eta ia asteazken osoan, harik eta Zuzendari txit agurgarriaren ukoa jaso nuen arte:

Mitxel Etxart, 73. gela: Aditzera ematen dizut ez dudala zure eskabidea onartzeko arrazoirik ikusten, eta bai arriskuak ugari... (37).

Etxart deitura, jakina denez, Iparraldeko aldaera da (gogora bedi Niko Etxart kantari altzürükütar ospetsua), bukaerako apokope eta guzti, zeren Hegoaldean Etxarte aldaera aurkitzen baitugu. Beste euskal deitura anitzek bezala, leku-izen bat $\mathrm{du}$ jatorri. Lertxundiren esanetan, lehendabizi izena etorri zen, Mitxel, eta gero deitura, tx-rekin eta bi silabarekin Mitxel biribiltzen duena eufonikoki.

Beste kasu batean ere nortasuna ez ezik, izena ere ezkutatzen zaigu obra guztian zehar: zuzendari txit agurgarria gisa agertzen zaigunaz ari gara.

Eta azken aipu antroponimiko bat: aurreko zenbait obratan bezala, hemen ere Lertxundik prosopopeia baliatzen du (Izotz, Herio):

(...) bat-bateko argi-eztanda batek argi berria eman dio esaldi zaharrari:

«Etorriko da Izotz eta zure begiak izango ditu» (87).

9 Lertxundiren esanetan, Ada izena, Nabokoven Ada or Ardor: a Family Chronicle nobelatik hartu zuen, «nobela hartako Adaren erreferentzia duenak jakin dezan nire irudimeneko Adaren berotasuna nolakoa den".

10 Izen aranatar hau «germaniar etorkia zuen Clodovicus izen latinotik dator» (http://www. euskaltzaindia.eus). 
1998an, Lertxundik Lehorreko koadernoa plazaratu zuen, literaturari egindako beste omenaldi bat (oraingoa Robert Louis Stevensoni eta haren Treasure Island-i), ${ }^{11}$ aurreko obretan baino idazkera arinagoa erabiliz. Kultura erreferentzia askotarikoen (literario eta musikalen) jolasa hitz ordezkatzaile eta hitz ordezkatuaren arteko errimaren bidez iristen da

Kaioen bazka izateko batere gogorik ez zuen naugrafo errukarri honek mezua izenpetu zuen gero:

Rollingston Crusoe (11)

bai eta Carlan jada antzeman genituenak bezalako izen-kreazio berriak:

Irla ezezagun baten planoa aurkitzeko poz abenturazale batek emozionatzen ninduen; galtza-barrenak belaun pareraino jaso, txalupatik jauzi egin, uharteko hondartza bakartira txapla-txapla heldu, eta nire oinek hondarretan utzitako arrastoekin uhartea bataiatzeko aukerak irrikatzen ninduen:

Rollingston Island (16)

Logikoa denez, adin bateko pertsonaien izenak ez dira aranatarrak, baizik eta bat egiten dute garai hartako euskal gizartearen kanon antroponimikoekin: Roman, Klaudio, ${ }^{12}$ Pilar, etab. Eleberria lehenengo pertsonan idatzita dagoenez, ez dakigu nola duen izena protagonistak harik eta istorioa nahikoa aurreratuta egon arte, Pilar gaztetako maitaleak idatzitako gutun bati esker («Sentitzen dut, Roman», 27).

Haren nortasuna poliki-poliki ezagutuz doa irakurlea: Klaudio Aldabe adiskideak idazten dion geroko gutun baten bidez (75) jabetzen gara Korta duela lehenengo deitura (Jose Luis Korta traineru-entrenatzaile txit ospetsu eta Lertxundiren herrikideak bezalaxe, eta ez dirudi kasualitatea denik). ${ }^{13}$ Azkenik, haren bigarren deitura ere jakinarazten zaigu, Río de la Platan dagoenean hain zuzen ere:

Begiraleak pabilioi batera eraman ninduen, eta, ordenagailua pizturik, nire agirietan agertzen ziren datuen bila hasi zen. Pa-pa-pa-pa nire izena tekleatu, eta Roman Korta Esnal bati buruzko datu mordoa agertu zen patailan (93).

Espainierazko itzulpenean (Cuaderno de tierra firme), ordea, Lertxundiren bigarren deitura den Esnal horren ordez, Olariaga abizena ageri da. Antroponimiazko txantxa pribatu horiek (irakurleek, jakina, errepara ezin diezaieketenak) ez dira baka-

${ }^{11}$ John Flint kapitaina eta John Silver aipatuak dira liburu honetan. Hain zuzen ere, Roman izeneko pertsonaiak hondartzan aurkitutako mezua Pata de Palok sinaturik dago. Horixe da John Silverren ezizena espainierazko itzulpenean (Long jatorrizkoan eta Luxea euskarazkoan).

${ }^{12}$ Lertxundik bere lagun Claudio Rodríguezi egindako omenaldia da hau. Klaudio izeneko pertsonaia ezizen-sortzaile bikain gisa ageri zaigu:

Bihozkada batek bultzaturik, gutuna eta zortzi folio mekanografiatuak errepasatu nituen berriro.

$\mathrm{Ni}$, Rollingston nintzaion. El Doradoren ondoan, Pagotxamendi zetorren, euskal hiztegiek jasotzen ez duten hitz bat. Biotxustel izena asmatu zuen matxinatuen ontziko kapitainarentzat. Pedro Mari Otańo izenaren ordez, Kattarro zerabilen etengabe... (113).

13 Izan ere, «Korta» Antton Olariaga ilustratzaileak Lertxundi lagun minari esateko darabilen ezizena da. 
rrak. Zenbait orrialde lehenago, Romanek gutun bat bidaltzen dio grafologo kataluniar bati. Hartzailearen helbidea hau da:

Grafos Jaun txit tentea

Carrer del Comandant Jorge Giménez 121 (55)

08008 BARCELONA

Bartzelonako kale-izendegira jotzen badugu, egiaztatuko dugu halako izena duen kalerik ez dagoela. Lehorreko koadernoaren espainierazko itzulpenera jotzen badugu, egiaztatuko dugu itzultzailea, Lertxundiren beste lan askotan bezala, Jorge Giménez Bech dela, zeinari bere lagunarte literario gertukoenean «komandante» gaitzizenez deitzen zaion. Txantxak aurrera darrai itzulpen horretan ere: hor ageri den kale-izena

\author{
Señor Grafos \\ Calle del Comandante J. Majoral 121 \\ 08008 BARCELONA
}

ez dator bat jatorrizko testukoarekin. Erreferentzia, ordea, ez da aldatu, zeren J. Majoral horren atzean itzultzailea baitago ostendurik. Izan ere, itzultzaile izateaz gain, liburu-diseinatzaile ere bada Giménez Bech, eta zeregin horretan Junkal Motxaile ezizena erabiltzen du. Beste txantxa pribatu bat, beraz.

Klaudiok Romani bidalitako beste eskutitz batean, lagunari, bere izenez beharrean, ezizenez deitzen dio («Kaixo, Rollingston»), eta Romanek segida ematen dio jolas antroponomikoari, erantzun moduko gutuna honela sinatuz: «Roman (edo Rollingston sinatu behar diat?)».

Izen aranatarra duen pertsonaia bakarra Gorka Gainbide da. Protagonistaren bizilagun eta adiskide hau gaztea da, Euskal Herriko erregistro zibiletan neurri handi batean izen aranatarrekin sartu den belaunaldi batekoa. Hemen ere nahasten ditu Lertxundik errealitatea eta literatura: bere bizilagun batek, lanbidez ozeanografoa denak, eman zizkion eleberrirako behar zituen hainbat datu zientifiko. Izan ere, gogora dezagun Zarautza itsas korronteak bultzatutako botila bat dela istorioaren leit-motiva. Bada, bizilagun horrek, bizitza errealean ere, Gorka ${ }^{14}$ du izena, eta Bidegain deitura. Lertxundi bere pertsonaien izenekin jolasten da berriz ere, deitura bihurtutako lekuizenaren osagarriak hurrenkeraz aldatuz.

Eleberriaren pasarte batean Antonbeltz aipatzen da. Liburu honetan ez ezik, geroko beste batean (Konpainia noblean-en) ere Lertxundik jasotzen duen Ondarroako istorio zahar baten protagonista dugu Antonbeltz. Esan gabe doa gaitzizenak oso ohikoak direla euskal gizartean (gizarte guztietan bezala, jakina), eta hemen ere ikusten dugula idazle gipuzkoarrak ahozko tradiziotik, kontu zaharretatik istorioak (oraingo hau, benetakoa) jasotzeko duen zaletasun handia.

Halaber, Lertxundik bere ideia gustukoenetako bat dakar hemen hizpidera: edozein kulturatan, Euskal Herrikoa barne dela, aurki ditzakegula unibertsala eta partikularra. Kultura ezberdinen artean badaudela hainbat antzekotasun. Esaterako, Amazonas aldeko herrien mitologiak eta Euskal Herrikoak zenbait mito partekatzen dituzte, izen ezberdinak izanagatik ere. baitu).

${ }_{14}$ Aranak eta Eleizaldek asmatutako izen hau grekotik dator (Georgos, zeinak «nekazaria» esan nahi 
Neuk ere irribarre egin nion. Nire jatorrizko tribuan ere oso antzeko kontakizun bat genuela. Guk lamia deitzen geniola beren Yarari. Edo Anbotoko dama... (106)

Liburuaren bukaeran, «Pata de palo» ezizenaren atzean ezkutatzen denaren nortasuna asmatzen saiatzen da Roman, baina misterioa ez da argitzen. Epilogoan Lertxundiren hitzak aurkitzen ditugu, lehenengo pertsonan:

Hurbildu, eta neure burua aurkeztekotan egon naiz. «Pata de Palo? Romanek nire esku utzi zituen bere paperak eta egunkaria...»

Baina ez dut pausorik eman.

Beren distira gordetzen dakiten misterioak dira benetako altxorrak (122).

Hemen idazle oriotarrak irakurleari azaltzen dio zergatik erabaki duen mezua botilan bidali zuenaren nortasuna ez agerraraztea: uste eta aieruan oinarritutako testu honetan ez zukeen zentzurik izango misterioa salatzeak.

1999an Lertxundik Muga-mugako zirriborroak (Edo pipiñoen kanpaina baten lehendabiziko zirriborroak) saiakera argitaratu zuen, Andrés Nagel eskultore donostiarrari eskainia. Saiakeratik ez ezezik, narraziotik ere baduen lan honek Berbelitz du pertsonaia nagusi. Lertxundik berba, ele eta hitzetik sortutako ezizen konposatu hori baino hoberik ez zaigu bururatzen halako pertsonaia berritsu batentzat. Izena duenak izana ere baitu.

2002an, aurreko lanetako erregistro jasotik urrunduz (hots, Lehorreko koadernoan hasitako ildoari jarraiki) eta hurrengo eleberrietan nagusituko den idazkera xumeago bat lehenetsiz, Zorion perfektua publikatu zuen Lertxundik. Istorio dramatiko bat kontatzen digu izenik aipatzen ez zaion piano-jotzaile protagonistak; hamalau urte geroago gogoratzen du nola hamasei urte zituela ETAren hilketa baten lekuko bakarra izan zen eta nola bizi izan zituen ondorengo hogeita lau orduak. Aingeru Epaltzak ironiaz dioskunez (2003), Lertxundik ez zion izenik jarri protagonistari lekuko babestua izateagatik («Ez zaigu haren izena ematen. Segurtasun arazoak, akaso»). Lertxundik, aldiz, azalpen oso ezberdina ematen digu: izenik ez emanez, drama hura pertsona jakin batengan fokalizatzea saihestu zuen, gertatutakoa edozeini gerta zekiokeelako eta errealitate bortitzak jende oro zipriztintzen zuelako inpresioa sortzeko. Hori guztiz bat dator autorearen obra osoaren alderdi etikoarekin: istorioa, istorio izateaz gain, Don Juan Manuelen Lucanor kondearenen moduko «enxiemplo» bat ere bada, karga moral handi eta guzti.

Zenbait aldiz, Lertxundik malabarismoak egin behar ditu protagonista izendatzeko tentaldian ez erortzeko ( «Tabernatik irtetera nindoala, nesketako batek ikusi egin ninduen. Nire izenez deitu zidan. Denek jiratu zuten burua», 134). Jabi Elortegik 2003an zuzendutako film-bertsioan, ordea, protagonistari izen bat eman zitzaion, Ainhoa, argi eta garbi geratuz zineak eta literaturak bide (eta baliabide) ezberdinak izaten dituztela sarri askotan. Lertxundik liburuan filmean bezala jokatu balu, aurreko aipua honela geratuko zatekeen, irakurleak protagonistaz duen ikuspuntua erabat aldaraziz: «Tabernatik irtetera nindoala, nesketako batek ikusi egin ninduen. "Ainhoa", deitu zidan. Denek jiratu zuten burua».

Zorion perfektua «antiantroponimiko» izenda dezakegun eleberri bat da. Eta hori ez da soilik protagonistaren izenik aipatzen ez delako: kontua da ez dakigula nola duten izena gainerako pertsonaia gehienek ere. Adibidez, istorioa lehenengo pertsonan kontatuta dagoenez, piano-jotzaileak aitaz, amaz eta aitonaz hitz egiten du, baina ez 
dakigu nola deitzen diren. Institutuko kimikako eta literaturako irakasleak ikasleek jarritako ezizenez aipatuak dira: hurrenez hurren, Perti (zeinari buruz protagonistak berak aitortzen duen: «Ez naiz gogoratzen zein zuen izena», 100) eta Txikierdi.

Literaturako irakaslea emakume txiki bat zen. Ilea motz-motza eramaten zuen beti, eta esaldiak ere laburrak, doiak, maite zituen. Txikierdi deitzen genion (108).

Perti pertinente hitzaren apokopea da. Har bedi kontuan adjektibo hori maiz erabiltzen dela kimika gaietan. Areago, Lertxundik berak aitortu digunez, agian Perti da eleberriko pertsonaiarik pertinenteena. Bestalde, irakasle horrek ez dauka eragozpenik bere ezizena ikasgelan ikasleen aurrean aipatzeko, mozkor-mozkor eginda udaltzain bat jotzeagatik atxilotuta egon ostean.

«Nire aurpegia guztiz pertinentea da nire zaletasunarekiko: nire sudur gorri puztokote hau eta nire aurpegiko ubeldurak nori legozkioke ez bada ni bezalako hordi-lapa amorragarri bati?» (100).

Izenaz eta bi deiturez aipatua den pertsonaia bakarra, ordea, hil duten gizona da. Haren nortasunaz aldi berean jabetzen dira protagonista (albistea egunkarian irakurtzen duenean) eta eleberriaren irakurlea.

Argazki-oineko letrek ziztor amorratuak ematen dute, egundoko abiadan mugitzen dira, ezin ditut elkarrekin lotu. Begiak igurzten ditut, negarraren gandua kentzeko. Pixkanaka-pixkanaka, letrak baretzen dira eta argazki-oina irakurtzen dut. Ez da nire izenik ageri. Bai, ordea, hildakoarena.

Abel Ergoien Landa (88).

Bezperan, hilketaren gaia neskaren etxean atera zenean, etxekoek ez zuten hildakoaren izenik aipatu, hildakoa izendatzeak lotsa edo beldurra emango balie bezala-edo. Lertxundik hildakoarentzat aukeratutako izen-deiturek literatura oihartzun nabarmena dute, baina irakurlea horren jakitun ez egotea balitekeenez, erreferentzia zehazten du, berriz ere metaliteratura eginez, material literarioa (onomastikoa barne) aukeratzeko izan dituen zergatiak irakurleari azalduz.

Aitak atzo, telebistakoa ikustetik bueltan, ez zuen hildakoaren izenik aipatu, eta nik ez nion galdetu. Hildakoa edo trapitxeroa deitu diogu orain arte besterik gabe. Baina, bet-betan, hor non argazki madarikatuaren oinak izena jarri dion nik hilik erortzen ikusi nuen gizonari: Abel.

Izenak hildakoa humanoagoa egin duela iruditzen zait. Hurbilekoagoa.

Argazkia ikusteak egin didan inpresioa bizi-bizi, eskelen orrialdera jotzen dut. Denetan txikiena da. Beheko partean dago, eskela handiagoen azpian erdi galdurik, lotsaz bezala. Baina horraxe zuzenean joan zaizkit begiak.

Abel, berriro.

Inoiz entzuna nuen Abeli eta haren anaiari buruzko ipuin biblikoa, baina Abel izenak Unamunoren Abel Sánchez nobelaren titulua ekarri zidan gogora eta baita etikako irakasleak arbelean idatzi zuen handik hartutako esaldi bat ere: «Zergatik jaio ote nintzen gorrotozko lurralde batean?». Klase osoan jardun genuen esaldia eztabaidatzen (88-89).

Dudarik gabe, neskak kultura maila polita du, zeren hamasei urteko ikasle euskaldunen artean ez baitira asko izango Unamunok Abel Sánchez idatzi zuela dakitenak. 
2004koa da Konpainia noblean liburua. Genero aldetik ez da sailkatzen erraza liburu hau, geriatriko batean bizi den idazle baten 93 narrazio laburrez osatua. ${ }^{15}$ Konpainia noblean? Zeren edo noren konpainian? Gure opilari su ematea leporatuko ote zaigun beldurrari muzin egin eta honatx gure hipotesia: euskal kultura ${ }^{16}$ tradizioaren pertsonaien izenen konpainian. Izan ere, liburu honi egin zion kritikan, Gema Lasartek (2004) «izen-festa» gisa definitu zuen. ${ }^{17}$

Liburuaren hasieran ageri den José Bergamínen poemak argi eta garbi erakusten digu antroponimoek bizitzan (oro har) eta literaturan (partikularzki) duten garrantzia. Alda daiteke gure nortasuna, alda daiteke gure itxura fisikoa, baina ez gure izena, beti lagun izango baitugu, non ez garen joaten erregistro zibilera beste bat hautatzera. Lertxundik Bergamínen poemaren bigarren eta hirugarren ahapaldiak dakartza, euskaraturik, lehenengo ahapaldia kenduta, ziurrenik ahapaldi hori euskaratzeak dituen zailtasunengatik. Guk espainierazko jatorrizkoa dakargu hona, osoosorik.

\section{María Chucena, ${ }^{18}$ tu nombre}

Es un nombre y nada más:

Tú no tienes una choza

Para poderla techar.

No tienes brazos ni manos;

No tienes pies para andar;

No tienes boca, ni ojos,

$\mathrm{Ni}$ oídos para escuchar.

$\mathrm{Ni}$ siquiera tienes alma

Para poderte soñar.

Tú no tienes más que un nombre

Que yo no puedo olvidar.

\footnotetext{
15 Honatx Juan Luis Zabalak liburuaren aurkezpenaz Berrian idatzi zuena (2004-6-9): «Idazleek ohiko arau eta moldeetatik ihes egiten duten neurrian, gero eta zailago da liburuak zein bere sailean zuzen, ziur eta modu egonkorrean kokatzea. «Narrazioa» da Anjel Lertxundik Alberdania argitaletxearen eskutik kaleratu duen liburu berria, Konpainia noblean; halaxe definitu zuen egileak berak, nobela edo ipuin liburu den zehaztu gabe, atzo Donostian egindako aurkezpenean: «Narrazio bat da, eta narrazio horrek narrazio asko ditu bere barnean bilduta, mosaiko baten antzera». Koldo Izagirre idazlea izan zuen aldamenean Lertxundik; "nobela balitz bezala" irakur daitekeela esaten ausartu zen Izagirre. Inazio Mujika Iraola editorea izan zen zuhurrena: Konpainia noblean "liburua" dela esan zuen, ez ironiarik gabe». Esanguratsua da Zabalak «ausartu» eta "zuhurra» hitzak erabiltzea, liburua genero aldetik sailkatzeko zailtasunen erakusgarri.

${ }_{16}$ Mitologia (deabruak pribilegiozko tokia du berriro ere Lertxundiren literaturgintzan), musika, literatura, etab.

17 «Izenak dira narrazio bakoitzaren iturburu eta oihartzun. Koldo Izagirre idazleak narrazio bilduma honen aurkezpenean ondo esan zuen modura, Anjelek zientzia berria asmatu du: onomastikalogia. Izenek, izen propioek, ezagunak egiten zaizkigun horiek, gure iragana eta oraina ezkontzen dituzte bakoitzarentzat istorio propioak sortuz».

18 María Chucena ahokorapilo honen protagonista da: María Chucena su choza techaba. Un techador que atento miraba le dijo: "QQué haces, María Chucena, techas tu choza o techas la ajena?" "No techo mi choza ni techo la ajena, techo la choza de María Chucena».
} 
Letrak kalekantoitik gogora dakarkigun liburu honetan oroimen kolektiboa berreskuratzen ahalegintzen da berriz ere Lertxundi, ${ }^{19}$ istorio eta kanta zahar horiek guztiak berridatziz eta berrasmatuz. Hona hemen adibide bat: Etxahunen bertso famatu baten gai izan zen bi zaharren amodioa oinarritzat hartuta, geriatriko batean bizi diren bi zaharren maitasun istorioa kontatzen digu Lertxundik. Urkiolako baselizan ezkontzen dira, nola ez. Eta Lertxundiren testuak "Maria Solt ta Kastero du izena», nola ez.

Konpainia noblean liburuan, Lertxundik bi aukera ematen dizkio irakurleari: irakurleak antroponimoaren jatorria (ageri deneko abesti edo istorioa eta bertan antroponimoak jokatzen duen rola) ezagutzen badu, antroponimoak arrastoak emango dizkio Lertxundik istorioa birsortzean erabilitako trepetak deskodetzen. Aitzitik, irakurleak erreferentzia hori ezagutu ezean, birsormena sormena balitz bezala irakurriko $\mathrm{du}$, arrastorik gabe, konparatzeko objekturik gabe.

Izen batek oroimenaren pizgarri gisa bete dezakeen oihartzun funtzioa maiz aldarrikatu du Lertxundik bai praktikan (haur literaturan), bai teorian (bere blogean).

Aski da izen bat, aski da hotsen bilduma laburra beste deus ez den testu bat, oihartzun ugarien mundu bat sorrarazteko. Hitz bat hotsen arteko ospakizuna da beti. Eta poesia bat, baita apalena ere, hitzen arteko txirikorda armoniatsua baita, hotsen ospakizuna da guztiaren gainetik. ${ }^{20}$

Blogeko beste testu batean («Izenei irri», Letrak sare-kantoitik, 3, Berria, 2009-2-4), kopla batzuk gogorarazten dizkigu Lertxundik, non errima edo aliterazioa dituzten izen eta ezizenak ageri diren: Antonio Polonio, Jose Moxe, Patxi Putxi, Bixente Inuxente. Errima nahitaezkoa da ezizenaren eta bertso-lerroetako bukaerako hitzen artean («Patxi Putxi, / ipurdia itxi»). Idazle oriotarrak hala eskaturik («Honaino iritsi zara eta badakizu zein den Letra sare-kantoitik honetako eskabide ohikoa: anima zaitez ezagutzen dituzun horrelako egituren berri ematera»), zenbait irakurlek adibide gehiago gaineratu zituzten blogean, hala nola:

Joxemari patatari lau hanka ta bost belarri.

Joxe, beti jan da beti gose, edan da egarri. Joxe beti parregarri.

Inaxio palaxio jan ta edan despaxio.

Ogia purra purra, Inaxio lapurra.

Gartzia, arraska zak atzia!

Antonio Polonio, pasa por aquí, errotako astuak erderaz daki ${ }^{21}$.

Ugari dira, bestalde, Konpainia noblean-en aipatzen diren izenak. Honatx haietariko batzuk:

- Abaxi. Azkue eta Lhanderen hiztegietan ageri den izen hori Lertxundik jadanik Letrak kalekantoitik liburuan iruzkindu zuen. Oraingoan esaten digu euskaldu-

${ }^{19}$ Helburu bera dute euskal kulturaren beste hainbat agerpenek ere. Ruper Ordorikak «Memoriaren mapan» diskoan (2006) Joseba Sarrionandiaren zenbait testuri musika jartzen dienean, oroimen hori ez da jorratzen antroponimiaren bidez, toponimiaren bidez baizik. Halaber, Bernardo Atxagaren Soinujolearen semea eleberrian (2003), Joseba pertsonaia nagusiak pospolo kaxa baten barruan euskararen hainbat hitz zahar lurperatzeko zeremonia ospatzen du, Estatu Batuetan, alabekin batera.

20 «Izena izanaren izara», Letrak sare-kantoitik, 9, Berria, 2009-2-12.

${ }^{21}$ Hemen kode-aldaketa (code-switching) gertatzen da, ahozko euskaran hain ohikoa den fenomenoa. 
nok ez diogula «ipuin bakar baten pozik eman izena besterik ezagutzen ez diogun» lapur horri (10).

- Kontxexi. Lertxundiren esanetan, María Concepción de Bengoetxea delako baten ezizena da. Gogora bedi, bestalde, 1986tik 1990era bitartean Lertxundiren sei haur liburu argitaratu zirela, polizia generokoak eta oso umoretsuak, Madame Kontxesi-Uribe, Brigada \& Detektibe izeneko saila osatuz. Jada aipatu dugun ezaugarri bat antzematen da Kontxexi izenean: euskal antroponimoetan palatalizazioak erabiltzeko joera. Orobat gertatzen da Konpainia noblean-eko zenbait mikrokapituluren izenburuekin, zeinak euskal kantutegi eta bertsolaritzatik ateratakoak diren: "Joxe Miel» ("Joxe Mielen batela» kanta ezagunarena), "Juana Bixenta Olabe» (Bilintxen bertso ospetsuarena), «Pello Joxepe», etab.

- Batista Bazterretxe: euskal kanta herrikoi ezagun honetan gurdi baten ardatza lapurtu izana egozten zaio Batista delako bati. Lertxundi onomastikaren ur zurrunbilotsuetan murgiltzen da kanta honetako protagonistak zergatik duen Batista izena azaltzeko.

Baserritarrak lapurrari eman dion izena ere ez da xaloa, eta orain onomastikaren alorra erakarri nahi dut, diziplinen arteko joan-etorrien onurak neureganatuz, antropologiara. Batista izena eman dio gurdi-ardatzaren jabeak lapurtzat salatu duenari. $B a$ tista izena ematen zaie Euskal Herriko hainbat tokitan tipo lerdoei. Deitura ez da inozenteagoa: Bazter-etxe, tipo marjinal bat! Inon eta inoiz ikusi al da, Antero Apaolazak bere nobelako pertsonaiari Patxiku Txerren deitu zionetik, manipulazio onomastiko begi-bistakoagorik? Baina alferrik: errealitatearen muin benetakoa hitzen malabarismoarekin mozorrotzea irizten diote fakultatekoek hizkuntzak eman dezakeen arrasto orori (115-116).

- Amaia: jakina denez, substantibo eta Burgos, Guadalajara edo Galiziako lekuizen hau Navarro Villosladaren Amaya o los vascos en el siglo VIII eleberriaren protagonista emakumezkoaren izena ere bada. xx. mendeko azken hamarkadetan emakume-izen zabalduena izan zen Hego Euskal Herrian. Bada, Lertxundik etimologia berria asmatzen dio izen horri. Kontatzen duenez (edo, hobeto esanda, bere irudimenak kontatzen duenez), fraide baztandar batek behin esan omen zion Navarro Villosaladari izen horri buruz: «No es vascuence, sino latín» (148). Hain zuzen ere, hargin masoi baten mezu akronimo gisa azaldu zuen: Augurium Mortis Aperit Ianuam Averni.

- Antonbeltz: Lehorreko koadernoan narratutako istorioa berriz ere dakarkigu gogora Lertxundik: bi ondarroarrek Argentinako Panpan topo egin zutenekoa.

- Kalamatxino: egokia deritzogu kapitulutxo osoa hona ekartzea, zeren gogoeta interesgarri bat baitakar izenaz eta izendatutakoaz.

—Nola esan duk duala izena?

- Kalamatxino.

—Ez duk posible, ez haiz existitzen idazle batek behin asmatutako fantasian baino. Kalamatxinoa! Izen bat, letra batzuk, ez haiz besterik. Paperezkoa duk hire existentzia, irudimenezkoak dituk hire ahoa eta hire ahotsa, hire begiak eta hire pertzepzioa, hire bihotza eta hire sentimenduak.

-Eta hala banintz ere... Zergatik ari haiz hizketan letra batzuk besterik ez naizen honekin? (285) 
Hemen Lertxundik ez digu izen horri buruzko argibiderik ematen, baizik eta onomastikaren gaineko iruzkin labur bat helarazten digu. Nolanahi ere, $L e-$ trak kalekantoitik-en ere glosatu zuen izen hori: bere hitzetan, jada existitzen ez den animalia bat da. Gainera, aurreko aipuan ageri den idazlearen izena ematen digu: Juan San Martin, zeinak honela dioen Zirikadak liburuan: «(...) egin zuen kalamatxinoak harrapatzeko plan bat».

- Beste mikrokapitulu batean («Txakur txiki gorritxo bat», Inazio Mujikak liburuari egindako ekarpena), bada Arginberriko Auxtin izeneko pertsonaia bat. Izendapen horretan badira aipatu ditugun euskal antroponimiaren bi ezaugarri: euskal baserri giroko gizartean jendea bere sortetxeagatik ezagutua izatea, eta erdal izenei euskarara pasatzerakoan jartzen zaien «mozorro» fonetikoa (Auxtin izenari dagokionez, txistukariaren palatalizazio hipokoristikoa eta bokal arteko kontsonante leherkariaren galera).

Edozein kasutan, mikrokapitulu «antroponimikoena», duda izpirik gabe, «Anton eta Patxi eta...» da (204-206). Hor, Peru Mintegiaga hizlariak (begi bistakoa da Lertxundik deitura aukeratzean erakutsitako umore fina) «Izena nolako, izana ere halako" gaiaz dihardu. Entzule daudenen artean, besteak beste, Lertxundi bera eta bere adiskide Leandro daude. ${ }^{22}$ Mintegiagak euskal tradizio onomastikoak aletzen ditu hitzaldian: katolikoa, erromantikoa, sabindarra, iraultzailea. Haietako bat hizpide duen bakoitzean, entzule multzo batek alde egiten du aretotik. Hitzaldiaren bigarren zatian, Mintegiagak pertsonifikazioen gaiari heltzen dio, hainbat izenek zer sinbolizatzen duten azalduz: Petirisantzek gosea, Txominek loa, Martinek bizkortasuna, Kattalin eta Maritxuk zurruta eta Anttonek xalotasuna. Azken izen horren zenbait adibide ditugu ahozko tradizioan: Anton Txanpon, Anton Kaiku, Anton Porru. Xalotasuna haragitzen duten beste izen batzuk honako hauek dira: Peru, Pello, Battis eta Marixe. Bidenabar esanda, Peru eta Marixe, mila eta bat komerixe haur liburuan (1993), Lertxundik Euskal Herri eta Europako ahozko tradizioaren istorio anitz kontatu zituen, ohikoa duen umoreaz zipriztinduta. Zertan oinarritu ote zen bi antroponimo horiek hautatzerakoan? Erantzuna, beste askotan bezala, Letrak kalekantoitik liburuan aurkitu dugu: 303. orrialdean, «aspaldian» esan nahi duen «Peru eta Marixeren aldian» esapidea iruzkintzen du Lertxundik.

Baina itzul gaitezen "Anton eta Patxi eta...» mikrokapitulura: hitzaldia bukaturik, hiru entzule baino ez daude aretoan: Anjel, Leandro eta Mintegiagaren emaztea. Bukaera barrez lehertzeko modukoa da, antroponimiari esker:

Kalera irten ginen. Garagardo bat hartzera joan ginen laurok eta, hitzari hitz, emakumea Peruren emaztea zela jakin genuen. Peruk ez zigun haren izenik esan, eta ni ez nintzen galdetzera ausartzen. Leandroren begietan pikardiazko distira bat antzeman nuen eta, halako batean, espero nuena gertatu zen, oihu bat entzun baikenuen tabernaren beste aldean:

—iMarixe!

Emakumea jiratu egin zen.

Leandrok eta nik nekez eutsi ahal izan genion barreari.

Gero, lau kantoiko txanpon bat bilatu izan bagenu baino pozago itzuli ginen etxera (205-206).

22 Bide batez esanda, Lertxundi bizi den kalearen izena Don Leandro da. 
2006koa da Ihes betea eleberria. Azkenaz beste bezala, ez dago Euskal Herrian giroturik. Izenburuak dioen moduan, ihes baten istorioa da, kanpo eta barne bidaia baten kontakizuna. Hurrenez hurren, Alemanian, Italian eta Frantzian kokatzen da. Protagonistak, Zorion perfektuakoak bezala, bere iraganaldiko gertaerak oroitzen ditu. Eta pertsonaia nagusiaren bilakaerak, Kapitain Frakasan jazotzen den bezalaxe, ondorio antroponimiko bat du: izen-aldaketa. Izan ere, Werner Lindemann gazte alemaniar hitlerzaleak, bere jatorri judua ezagutzean, sinesten zuen mundua urratzen ari dela ikusten du, eta bere ihesean nortasun berria, izen berria hartzen: Ernst Lange. Kapitain Frakasan legez, pasaporte-dantza bati, nortasuna ezkutatu beharrari lotuta dago izen-dantza.

Amona Erikak gelatik irteten ikusi ninduenean, zerbait atera zuen harizko jakaren patrikatik poz-errainuzko aurpegi batez:

Ernst Lange jauna, ongi etorri aleman pasaportedunon mundura, eta pasaporte bati eta permesso di soggiorno bati eragin zien airean (167).

Ernst Lange, geroago (330), beste nortasun batek ordezkatzen du Frantziako ibilbiderako: René Bourgeois izenarenak.

Helbidea galdetu nion. Ez zuen gogoan. Pazientzia bildurik, adiskidearen izen-deiturak eskatu nizkion.

René Bourget. Ez, barkatu, René Bourgeois.

Bourget ala Bourgeois?, nik.

Negar egiteko zorian zegoen.

Nortasuna aldatuz joan beharra nolabaiteko umorez onartzen du protagonistak.

Anghiosen etxetik alde egitera nindoala hark emandako helbidean ostatu hartzeko, Müller jauna izan zen eskua eman zidana:

Je vous remmercie infiniment, monsieur... monsieur..., eta hor trabatu zen gizajoa ez atzera ez aurrera.

René Bourget... Ez, ez, barkatu, René Bourgeois..., erantzun nion nik, Dijoneko geltokian izan genuen eszenatxo irrigarria gogoan, eta neurtu gabe nola hartuko zuen nire txantxa.

Müller jauna algara batean hasi zen. Asko poztu ninduen hain gizon prestu batek umorea zuela ikusteak (339).

2008an, Lertxundik Zoaz infernura, laztana plazaratu zuen. Genero-indarkeriazko istorio hau benetako gertaera batean oinarriturik dago eta hiru ahotsek kontatua da. Liburuaren kritikariek eta editoreak «nobela beltz» eta «nobela psikologiko» gisa definitu zuten. Protagonistak bi senar-emazte dira: Tomas eta Rosa. Bi izenok, jakina denez, hainbat hizkuntzatan daude. Tomas izen aramearra da, «bizkia» esan nahi duena eta grekora eta latinera igaro zena. Antroponimo emakumezkoaren euskarazko aldaeretako bat Arrosa da, euskarak $r$ kontsonantearekin hasitako maileguei bokal protetiko bat eransteko duen joeragatik. Eta aldaera sabindarra, Errose. Gainerako pertsonaien izenak Inazio, Amalia eta Manu dira. Lertxundik pertsona-izen mota hau ${ }^{23}$ aukeratzeko izan zuen ustezko zergatia Hamaseigarrenean aidanez hizpide izan ge-

23 Bost izenetako bat ere ez da aranatarra. 
nuenean azaldu genuen bera da. Kontuan hartu behar da garai bertsuko obrak direla. Baten batek pentsa lezake ez dirudiela oso egokia "garai berekoak» direla esateak, zeren eta bataren argitalpen urtetik bestearenera mende laurdena igaro zen. Hala ere, badago datu bat garaikideak direla pentsarazten diguna: Zoaz infernura, laztana, nolabait ere, Lertxundik aspaldiko zor bat kitatzeko zuen asmoaren emaitza izan zen. Liburuaren aurkezpenean eta jendaurreko beste agerraldi batzuetan, nola edo halako injustizia literario baten gisa azaldu zuen: xx. mendeko 80ko hamarkadan, Hamaseigarrenean aidanez kaleratu eta handik lau urtera, genero-bortizkeriazko benetako gertaera batean funtsaturiko «Gau errean» izeneko ipuina argitaratu zuen, Plazara aldizkariko 1987ko 9. zenbakian aurrena eta Taberna zuloko ipuinak bilduma kolektiboan geroago. ${ }^{24}$ Ipuinaren oinarria hilketan inplikatuetako batek epaileari egindako aitorpena zen. Baina Lertxundi, bere esanetan, une hartan ez zen biktimaz errukitu, ez zen haren larruan jarri, istorioan sartuegi zegoen. Eta idazlea Mabel izeneko emakume harekin gogoratzea eta emakume horrekiko jarrera berria izatea erabakigarriak izan ziren, urte anitz geroago, Zoaz infernura, laztana idazteko. Horrexegatik esan daiteke eleberri hau eta Hamaseigarrenean, aidanez garai bertsukoak direla.

Genero-indarkerian antroponimiaren manipulazioa baliabide eraginkorra izan daiteke gizonarentzat. Oso adierazgarria da Tomasek Rosarengana zuzentzerakoan txikigarria erabiltzea ("Lasai, Rosita, ez kezkatu ezergatik, laster pasatuko da dena», 62) senar-emazteak sendagilearen kontsultan topatzen direnean senarrak emazteari eragindako tratu txarrak direla-eta. Txikigarriaren bidez, tratu txarren egilea bitan banatzen da: Dr. Jekyll eta Mr. Hyde da txandaka, biktimari beste aurpegia erakusteko: indarkeriaren ondorioak etxetik kanpo ikusteko modukoak direnean erakutsi nahi duen aurpegia. Tratu txarrak denen jakinekoak direnean erakutsi nahi duen aurpegia.

Hirugarren pertsonaia Inazio ${ }^{25} \mathrm{da}$, Manu anaia nagusi eta bakar duena. Inazio izena Ignatiusetik eratorria da. Azter ditzagun eratorpen prozesu horretan gertatutako aldaketa fonetikoak:

- Kontsonante murrizketa: $g n>n$. Jakina denez, halako lenizioak oso ugariak izan ziren euskarara latinetik etorritako maileguetan (castellum > gaztelu; conventus > komentu; peccatum > bekatu). Euskarak silaba egitura sinplea du, bokalak eta kontsonanteak txandakatzen dituena eta kontsonante metaketa saihesten duena.

24 Liburuko ipuinen egileak Lertxundik asmatutako akronimo baten gisa ageri dira nortasun bakarrean bilduta: Araligar Jualermu (Aristi, Aldekoa, Igarabide, Garzia, Juaristi, Lertxundi, Mujika Iraola).

25 Euskaltzaindiak hobesten duen aldaera Ignazio da. Honatx izen horretaz dioskuna (2001: 127):

Eneko Loiolakoak gure artean zabaldutako izena. Ignatius Antiokiako santu handia izan zen, eta berarenganako jaieraz hartu zuen Loiolakoak Ignazio izena. Gogoratu beharra dago Eneko ez zela kristau tradizioko izena eta horregatik beranduago desegokitzat emango zela, Trentoko kontziliotik aurrera ezinbesteko baitzen kristauek santutegiko izena izatea. Egnatius etruskotik sortu zen Ignatius, hura herri-etimologiaz ignis 'sua', 'garra' hitzarekin lotu baitzen. (...). Aldaerak: Inazio eta Iñaki (Sabino Aranak eta Koldo Elizaldek argitaratuko Deun-ixendegi euzkotaŕa). Hipokoristikoak: Inaxio, Iñizio... Baliokideak: Ignacio (gaz.) eta Ignace (fr.). 
— Kontsonate belarra jausita, aurreko bokal palatala eta kontsonante sudurkaria elkartzen dira. Ondorioz, bokalak palatalizatu egiten du kontsonante sudurkaria, bustidura hori grafian islaturik ez badago ere.

Badago laugarren pertsonaia bat ere: Amalia, Tomasen ama. Amaliak Rosa gorroto du («Rosak ezagutzen duen bizitza infernutik dago hurbilen, eta horren kulparen zati bat, ez guztia, baina kulpa, Amaliak du», 35). Hala ere, alzheimerrak jota zahar-etxe batera bidaltzen dutenean, Rosa bisitan joaten zaio.

Bigarren mailako pertsonaien izenik, ordea ez zaigu esaten. Bai, ordea, haien ezizenak. Bat Tomasen adiskidea da, lanbidez egurzalea («Apaiz izana da eta Apeza du goitizen, baina aurrez aurre inor gutxik deitzen dio horrela: gorroto du goitizena eta inork hala deituko balio, muturra hautsiko lioke», 42). Beste bat Tomasen tabernako beste bezero bat da, Batallas gaitzizena duena. ${ }^{26}$

Etxeko hautsa izan zen Lertxundiren hurrengo eleberria, 2011n argitaratutakoa. Bi plano ditu: lehenaldia eta orainaldia. Lehenaldian protagonistak (Jorgek) ETAko bi kide eraman behar izan zituen bere autoan herri batetik beste batera. Orainaldian, hogei urte igarota eta izena aldaturik (Jorge izena utzi eta Gorka izen baliokide aranatarra hartuta, horrek dakartzan konnotazio guztiekin), hogei urte lehenagoko giro hartaz idazten dio, aitorpen mingarri gisa, aita gaixoari, zeinak Julian Martiarena baitu izena. Liburuko 15. orrialdean jabetzen gara protagonistaren izenaz, aitari idazten dion gutunean aipatzen duenean aitak esandako esaldi bat gaixoaldiaren hasieraren garaikoa: «Gauza bitxia gertatzen ari zaidak, Jorge: telebista esan nahi dudanean, erloju hitza etortzen zaidak akordura. Eta alderantziz».

Jorge etakide batzuei laguntzeko konbentzitu zuena aspaldiko neskalagun bat da, inoiz ere bere izenez agertzen ez zaiguna, Jorgek hala erabakita ( Neskak —ez diot Neska beste izenik emango hemen — bere alde jarri ninduen hasiera-hasieratik», 16). «Neska» substantiboa izen berezi gisa erabiltzen da hemen, letra larriz idatzita baitago hasierako kontsonantea. Eta baliabide linguistiko horren bidez, anonimotasuna gordetzen da.

Nortasunaren ezkutaketak beste etakide batzuei ere eragiten die, klandestinitateak hala eskaturik, Kapitain frakasan-eta gertatu legez. Haietako bati Manu deitzen dio Jorgek, nahiz eta argi dagoen ez duela hori benetako izena.

Taldekideetako batek protesta egiten du ilun dagoelako, eta zutitu egiten da argia piztera. Bilera-buru egiten duenak — dei diezaiodan Manu — besotik heltzen dio eta eserarazi egiten du (27).

Ezizenak, beraz, eleberri honetako ezaugarri antroponimiko nagusi dira: ustez poliziaren salatari mozkortia den bati Moxo deitzen diote etakideek, Zakur Beltz, ordea, teniente bati, eta, bestalde, ezizenez deitzen diote elkarri.

Ederki, Ka-kapitain. Hemendik aurrera halaxe deituko diagu, Kakapitain, eta eransten du berari deitzeko Katxas, eta autoan sartu berria den lagunari, aldiz, Gorriya edo Gorritxo, aukeratzeko gehien gustatzen zaidana. Ez du ezer esan Neskagatik (114).

26 «(...) los vascohablantes han sido siempre muy dados a recurrir al espańol a la hora de crear apodos, a menudo expresados en forma plural: Barbas, Bienvenido, Culorroto, Lentes, Raquitín, Trapero, etc.» (Cid Abasolo, 2014: 30). Lertxundik berak halako goitizenen berri ematen digu "Balantxasen omenez» zutabean (Letrak sare-kantoitik, 7, Berria, 2009-2-9). 
Ohi bezala, literaturaz beste arte batzuei egiten die erreferentzia Lertxundik eleberri honetan. Eta zinemagintza da haietako bat. Jorgek Agustin tabernariari Azken tangoa Parisen filma eskatzen dio aita lokartzen denean ikusi ahal izateko. Eta eszena batean Marlon Brandok Maria Schneiderri hitzez hitz esaten dion zerbait oso antroponimikoa gogoratzen du Jorgek, filmaren giltzarritzat jo daitekeena: «Nik ez dut izenik, zuk ez duzu izenik. Hemen ez dugu izango izenik. Zuk eta nik bat egingo dugu hemen, kanpoan gertatzen denarekiko batere ardurarik gabe, ados?» (49).

Ibilbide antroponimiko lertxunditar honi amaiera emateko, idazle oriotarrak orain arte idatzi duen azken liburua aipatu behar da: $Z u, 2015 \mathrm{koa}$. Baten batek pentsa lezake nobela bainoago eguneroko bat dela, hibridotasuna duena ezaugarri gisa. Izan ere, liburuaren ardatz den narrazioa, idazlearen emaztea pankreako minbiziz gaisotzen denean hasten dena, idazlearen hausnarketez zipriztindurik dago, euskal eta munduko kulturaz (literaturaz, zineaz, musikaz...) makina bat aipu eginez. Lertxundik berak bi generoren arteko nahasketatzat definitzen du liburua testuaren barruan bertan ( «Zergatik ari den erdi dietario erdi saio honekin, Zure senarrak ez dauka garbi», 239). Dena den, eleberritzat ere jo liteke, eta argudio ezin gezurtatuzko bat baliatuko dugu hori baiesteko: Inazio Mujika editoreak liburuaren aurkezpenean esandakoak.

Liburuko testuak «dietario batekoak balira bezala idatzita» daude, Lertxundik azaldu duenez, baina «narrazioak eta kontakizunak darama eskutik irakurlea, baita liburuaren zatirik erreflexiboenetan ere», Mujika Iraolaren ustez, eta horrek $Z u$-ren nobela izaera berresten du. ${ }^{27}$

Liburu honek antroponimiaren ikuspegitik duen garrantzia izenburuan bertan islatzen da: «zu» bigarren pertsona singularraren izenordaina izan arren, hemen izen berezi gisa erabilita dago (hitz kategoria aldaketa honek gogora dakarkigu Etxeko hautsan "neska» substantiboarekin egindakoa, hura ere izen berezi gisa erabili baitzuen Lertxundik aurreko eleberri hartan). Horrexegatik agertzen da beti hasierako hizkia letra larriz idatzita. Minbiziak jotako gaixoari Lertxundik jarri dion izena da $\mathrm{Zu}$. Zergatik izen hori? Zu izenaren bidez, bizipen hori pertsona jakin batengan fokalizatzea saihestu du Lertxundik, gertatutakoa edozeini (baita eleberriaren irakurleei ere) gerta dakiokeelako inpresioa sortzeko. ${ }^{28} \mathrm{Bai}$, badakigu hitz hauek lehenago ere jarri ditugula artikulu honetan, Zorion perfektuaz ari ginenean. Gogora dezagun Lertxundik protagonistaren izena isilduz helburu bera izan zuela eleberri hartan.

$\mathrm{Zu}$ izenordaina izen berezi gisa erabilita dagoelako bigarren froga (lehenengoa, esan dugun bezala, lehenengo hizkia letra larriz idatzita egotea da) Zu hitzaren izen- eta aditz-morfologia da: ez dago izenordain gisa deklinaturik, izen berezi gisa baizik (genitiboan «Zuren» da «Zure» beharrean) eta aditzean ez dauka 2.

27 Zabala (2015).

${ }^{28}$ Lertxundik, ordea, beste arrazoi bat argudiatu zuen liburuaren aurkezpenean. Juan Luis Zabalak kronika berean dioskunez, «Lertxundiri «oso modu naturalean» bururatu zitzaion pertsonaia $\mathrm{Zu}$ izendatzea, eta iruditu zitzaion erabaki horrek biribildu egiten zuela nobelari eman nahi zion ikuspuntua. «Istorioa kontatzen duena ez da $\mathrm{Zu}$, baizik eta Zuren ondoan dagoen senar idazlea. Aldamenean dagoenarentzat, $\mathrm{Zu}$ da bestea, gaztelaniaz la otredad esaten dena, eta egoera muturreko batean ondoan dagoenak are premia handiagoa du beste horrengana iristen ahalegintzeko, bidea elkarrekin eta ahal den erosoen egingo badute». 
pertsona singularraren morfemarik, 3. pertsona singularrarena baizik («Minbizia dauka Zuk», 90).

Eleberri edo dena delako hau autobiografikoa da (hortaz, ez dago, aurreko eleberrietan ez bezala, kreazio antroponomikorik): bigarren protagonista gaixoaren senarra da. Ez da bere izenez aipatzen, baina aipatu beharrik ere ez dago, irakurleak badakielako senar hori Anjel Lertxundi dela, ${ }^{29}$ edo senar hori edonor izan daitekeelako, $\mathrm{Zu}$ edonor izan daitekeen bezalaxe. Izen bereziarekin beharrean, beti «Zuren senarra» edo «senarra» gisa agertzen da. Zuren senarra idazlea da, eta senar legez lehenengo pertsonan hitz egiten du ( $Z$ Zahartzen ari naiz eta nekea ere zahartzen ari da nirekin batera», 71); idazle legez, ordea, 3. pertsonan ("Zuren senarrak erruz hitz egiten du bere buruarekin», 111).

Beste pertsonaia batzuen izenak ere esaten zaizkigu, baina oharkabean bezala:

- Onkologoaren izen-abizenak (Sara Arévalo) 101. orrialdean jakinarazten zaizkigu, baina orrialde horretatik aurrera ere «(Zuren) onkologoa» izenaz aipatzen zaigu.

— Loli: eguneko ospitaleko arduraduna (182).

- Marina (26), senarra hil zaion emakumea.

- Elena, Sararen erizaina izandakoa eta egun «mugako gaixoen egoera hobetzeko ekimen aitzindarietan» ari dena lanean (274).

- Minbiziak jota hildakoak: Mariano, Nieves, Esther, Marije, Belen, Sebastian, Rosi, etab. (131).

- Lertxundiren lagunak ere beren benetako izenekin dabiltza han-hemenka, hala nola Jorge (Giménez Bech) eta Ramón Sánchez Lizarralde itzultzaileak. Hala ere, ezizenik ez da falta liburu honetan. Lertxundik eta bere andreak maiz sortzen dituzte goitizenak ospitaleko eremuan ezagutu dituzten pertsonak eta beren burua izendatzeko, horrela egoera larriari umorearen bidez aurre egin ahal izateko.

Txantxa berriak ere egiten ditugu: Epo-Mari deitzen diot Zuri, kimioak moto batena bezalako arrapataka batean jartzen duen aldiro. Gizontxo edo Aittona deitzen dit Zuk elurretan galdutako zozo batena bezalako nire itxura eta ibilerarengatik. Aingeru Guardakoa deitzen diogu ospitaleko ibileretan —eginkizun burokratikoetan, departamendu batetik bestera, medikuekin harremanetan...- hainbeste laguntzen digun Isabel lagunari. (...) Gure artean jarritako goitizen batzuk baliatzen ditugu hainbat erizain edo mediku izendatzeko: Amatxo, Mutua, Goierri, Konkis, Kariño... (180).

Liburu honetan, Lertxundiren gogoeta sakonek oinarri intelektual sendoa dute: munduko dozenaka idazleren ideiak eskaintzen dizkigu orrialdeotan, parafrasi gisa edo hitzez hitzezko aipu gisa. Thomas Mann, Albert Camus eta Susan Sontag lehenengo lerroan, baina baita beste anitz ere, hala nola Coetzee, Tolstoi, Szymborska, Dickens, Canetti, Mrożek, Márai, Kundera, etab. Eta euskaldun batzuk ere tartean: Xabier Lete, Imanol Zurutuza, Arantxa Urretabizkaia edo Lizardi, kasu. Beste alor

\footnotetext{
29 Eta hori ez dakienari esan behar diogu nahikoa despistaturik dabilela, Lertxundik, besteak beste, honakoa hau esaten duelako eleberri honetan: «Paper-festa, Alberdaniarentzat idazten ari naizen ipuin-liburua, martxa onean doa, pozik nago» (44).
} 
ugaritako artistak ere badabiltza harat-honat liburuan barrena. Zinemagintzakoak, ez gutxi: Buñuel, Greta Garbo, George Cukor edo Fernando Fernán Gómez. Arte plastikoetakoak (Elena Asinsena). Eta literatura pertsonaiak: Ivan Illitx, Telemako, Odiseo...

\section{Ondorioak}

Anjel Lertxundiren eleberriak eta kazetari-lanak aztertzetik ondorioztatzen da antroponimiarenganako zaletasun eta interes aparta. Bai Euskal Herrian bai handik kanpo kokatutako bere istorioetako pertsona-izenak nahita eta arretaz aukeratu izan ditu beti. Bestalde, liburu bateko baino gehiagoko zenbait pertsonaiaren nortasuna eta izena aldatuz doaz istorioak aurrera egin ahala. Ez alferrik, nortasuna (batez ere indibiduala, baina baita kolektiboa ere) egile honen gai nagusietako bat da.

Garaian garaiko eta tokian tokiko izenak aukeratu behar ditu beti idazleak, eta hala jokatzen du Lertxundik bere eleberri guztietan, hala nola Hamaseigarrenean aidanez-en. Leku- eta denbora-espazio hartan ohiko izenak erdaldunak ziren, eta artean hedatu gabeak ziren gerora Euskal Herri (euskaldun zein erdaldun) osoan arrakastatsu bilakatuko ziren izen aranatarrak.

Idazle oriotarrak, bere lan ugaritan, euskal kultura eta kultura unibertsala (literatura barne dela) omentzen ditu. Haren liburuetako orrialdeetan barrena aurki ditzakegu pertsonaia historikoak, idazle ospetsuak, eta idazleok sortutako pertsonaiak. Eta omenaldi honen barruan antzematen da euskal ahozko tradizioa (literarioa, musikala, mitologikoa) berreskuratzeko asmo sendoa, hori bai, aire berezi batekin, tradizio hori lertxunditurik. Anjel Lertxundi irakurle amorratua da, eta irakurritako materialak neurri handi edo txikiagoan berridazteko joera izaten du sarri askotan. Izan ere, literatura material guztia jada idatzita omen dago, eta gaur egungo idazleari geratzen zaion zeregina material horri buelta ematea omen da, haren ifrentzua bilatzea. Lertxundik gogora dakartzan mito eta pertsonen izenek irakurleen (adin jakin bateko irakurleen) buruan durundatzen dute, nahita bilatutako oihartzuna sortuz. Euskal irakurle gazteengan, ordea, zaila izango da halako oihartzunik gertatzea: hortaz, izen-festa honetara sartzearekin batera beren kulturarako bidaia iniziatiko bati ere ekingo diote.

Izenekin jolastea ohiko ezaugarri du idazle honen literaturak, ez bakarrik pertsonaia bat izen batetik bestera ibil daitekeelako, baizik eta, askotan, idazleak ez digulako pertsonaia baten izenik jakinarazten istorioa nahikoa aurreratuta egon arte, Bernardo Atxagak Zeru horiek-en egiten duen bezalaxe. Beste batzuetan (Zorion perfektua, Etxeko hautsa), izena eleberri osoan da ezkutatua. Eta muturreko beste kasu batean (Lehorreko koadernoa), arrazoi oso ezberdinengatik, ez zaigu inoiz jakinarazten nor den botila bat, «Pata de Palo» gaitzizenez sinatutako mezu eta guzti, noizbait itsasora jaurti zuena.

Izen-dantza honetan Lertxundiren inguruko pertsona errealek (bere bizilagun batek, bere lagunek, bere itzultzaileak) ere parte hartzeak argi eta garbi erakusten du erudizio erraldoi horren atzean borondate ludiko nabarmena ezkutatzen dela, osagarri hori ezinbestekoa baitzaio literatura on orori. 


\section{Bibliografia}

Arana, S. / Eleizalde, L., 1910, Deun-ixendegi euzkotaŕa edo Deunen ixenak euzkeratuta ta ixentzat ezarten diran jayetako ixenan euzkerazko ikurpenak, Bilbo, Bilbao marítimo y comercial.

Aranburu Oiarbide, M. / Sainz de Murieta, L.M., 1999, "Goitizenen araberako pertsonen kategorizazioa», Euskonews \& Media, 35, maiatzak 28. http://www.euskonews. com/0035zbk/gaia3502eu.html

Cid Abasolo, K., 2007, "Nombres vascos en Madrid», Los nombres del Madrid multicultural, Madril, Ediciones Parthenon, 65-98.

—, 2009, "Antroponimia en la literatura vasca contemporánea: Anjel Lertxundi», Los nombres de persona en la sociedad y en la literatura de tres culturas, Madril, Ediciones Sílex, 13-51.

—, 2010, «Nombre propio e identidad cultural vasca: la contribución del Euskal Izendegia Ponte Izendegia / Diccionario de Nombres de Pila / Dictionnaire de Prénoms", Nombre propio e identidad cultural, Madril, Ediciones Sílex, 11-28.

—, 2011, "Basque Anthroponymy in Madrid», 2nd Conference of the Luis Michelena Chair. Koldo Mitxelena Katedraren II. Biltzarra. 2. ${ }^{\circ}$ Congreso de la Cátedra Luis Michelena, J.A. Lakarra, J. Gorrotxategi, B. Urgell (arg.), Koldo Mitxelena Katedraren argitalpenak, Gasteiz, EHU, 599-620.

—, 2012, "Deonomasticæ Vasconum Primitiæ», La suerte de los nombres propios, Madril, Ediciones Sílex, 35-63.

—, 2014, "Nombre oficial y nombre familiar en la lengua vasca», Del nombre oficial al nombre familiar (Ápodos, sobrenombres e hipocorísticos), Madril, Ediciones del Orto, 15-42.

Epaltza, A., 2003, "Aro beltzaren neurriko», Nabarra, apirileko alea.

Euskaltzaindia, 2001, Euskal izendegia. Ponte izendegia. Diccionario de nombres de pila. Dictionnaire des prénoms, Gasteiz, Eusko Jaurlaritzaren Argitalpen Zerbitzu Nagusia.

Jimenez, E., 1989, «Obabakoaren umea ei da Karla», Argia, uztailak 17.

Lasarte, G., 2004, «Memoria osatze aldera», Berria (irailak 25).

Lertxundi, A., 2009, «Izenei irri», Letrak sare-kantoitik, 3, Berria, otsailak 4.

—, 2009, «Balantxasen omenez», Letrak sare-kantoitik, 7, Berria, otsailak 9.

—, 2009, «Izena izanaren izara», Letrak sare-kantoitik, 9, Berria, otsailak 12.

—, 2009, «Marimin du grazia», Letrak sare-kantoitik, 10, Berria, otsailak 15.

San Martin, J., 1960, Zirikadak (Ipuin barregarridun liburua), Zarautz, Itxaropena.

Zabala, J.L., 2015, «Fikzioa idazkuntzan dago», Berria, azaroak 25.

\section{Artikulu honetan aztertutako Anjel Lertxundiren lanak:}

Hamaseigarrenean, aidanez, 1983, Erein.

"Gau errean», 1987, Plazara, 9 (bigarren argitalpena: in Taberna zuloko ipuinak, Erein). http://andima.armiarma.eus/plaz/plaz0914.htm

Tobacco days, 1987, Erein.

Carla, 1989, Erein.

Lurrak berdinduko nau, 1990, Erein.

Kapitain Frakasa, 1991, Erein.

Otto Pette (Hilean bizian bezala), 1994, Alberdania. 
Piztiaren izena, 1995, Alberdania.

Azkenaz beste, 1996, Alberdania.

Letrak kalekantoitik, 1996, Alberdania.

Argizariaren egunak, 1998, Alberdania.

Muga-mugako zirriborroak (Edo pipiñoen kanpaina baten lehendabiziko zirriborroak), 1999, KM.

Zorion perfektua, 2002, Alberdania.

Konpainia noblean, 2004, Alberdania.

Ihes betea, 2006, Alberdania.

Zoaz infernura, laztana, 2008, Alberdania.

Etxeko hautsa, 2011, Alberdania.

$\mathrm{Zu}, 2015$, Erein.

\section{Interneteko baliabideak}

Euskal pertsona-izenei buruz Euskaltzaindiaren webgunean informazioa bilatzeko esteka: http://www.euskaltzaindia.eus/index.php?option=com_content\&view=article\&id=253\&Ite $\mathrm{mid}=469$ \&lang $=\mathrm{eu}$

Dr. Karlos Cid Abasolo

Profesor Titular de Filología Vasca

Despacho 2.307.0

Edificio D, Facultad de Filología

Universidad Complutense de Madrid

C/ Profesor Aranguren, s/n

Ciudad Universitaria

28040 Madrid

abasolo@ucm.es 